\title{
Protein absorption and ammonia production: the effects of dietary protein and removal of the colon
}

\author{
By J. A. GIBSON, G. E. SLADEN AND A. M. DAWSON \\ Department of Gastroenterology, St Bartholomew's Hospital, London $E_{1} A_{7} B E$
}

(Received 21 March 1975 - Accepted I 5 May 1975)

\begin{abstract}
I. The effect of increasing dietary protein content on the amount of faecal nitrogen was measured in six normal subjects and five subjects without functioning colons (three with ileostomy and two with ileo-rectal anastomosis).

2. There was a significant increase in the amount of faecal $\mathrm{N}$ with increased dietary protein content in the subjects without functioning colons.

3. In normal subjects with intact colons, faecal $\mathbf{N}$ content was found to be lower than that in subjects without colons, and furthermore there was no significant variation with diet.

4. The source of the increase in faecal $\mathrm{N}$ with increased dietary protein content in subjects without functioning colons is discussed and the significance of these findings in relation to the efficiency of protein absorption is considered.
\end{abstract}

The improvement in hepatic encephalopathy which follows purgation and enemas (Schenker, Breen \& Hoyumpa, I974) supports the general belief that the colon is the primary site of ammonia production in man. The successful treatment of this encephalopathy and the reduction in blood $\mathrm{NH}_{3}$ which results from dietary protein restriction (McDermott, Adams \& Riddell, 1954; Sherlock, Summerskill, White \& Phear, 1954; Sherlock, Summerskill \& Dawson, 1956) therefore suggest that variation in the amount of dietary protein has an effect on the amounts of nitrogenous compounds entering the colonic lumen from the ileum. The extent of this process in man has never been measured and we have therefore determined the effect of varying dietary protein content on the amount of nitrogen entering the colon, as part of a study of the origin of gastrointestinal $\mathrm{NH}_{3}$.

\section{METHODS}

\section{Subjects}

The six control subjects were either members of the medical staff of the hospital or patients with no evidence of small intestine or large intestine disease. Ileal $\mathrm{N}$ output was estimated in five other subjects, three with an ileostomy, one with an ileo-rectal anastomosis following colonic exclusion and one with an ileo-rectal anastomosis following colectomy, all of whom had undergone operation at least I year before this study and showed no evidence of recurrent disease, ileostomy dysfunction or obstruction at the ileo-rectal anastomosis. Informed consent was obtained from all subjects.

\section{Diets}

All subjects were given a low ( $40 \mathrm{~g} / \mathrm{d})$ - and a high ( $100 \mathrm{~g} / \mathrm{d})$-protein diet. The diet were isoenergetic $(10.5 \mathrm{MJ} / \mathrm{d})$, and the low- and high-protein diets provided $(\mathrm{g} / \mathrm{d})$ 
respectively: protein $40 \cdot 2$, I0I.2; carbohydrate 290,210 ; fat $133,136 \cdot 5$. Meals were prepared in the hospital diet kitchen and given in a general medical ward. The blood urea concentrations for ten of the eleven subjects were estimated for each diet using the diacetyl monoxime method (method no. $\mathrm{SF}_{4}$ oor $\mathrm{FC}_{4}$; Technicon Instruments Co. Ltd (1964)) using an AutoAnalyzer (Model 6/60; Technicon Instruments Co. Ltd, Basingstoke, Hants).

A 5 d equilibration period was allowed with each diet for control subjects (Martin $\&$ Robison, 1922), but this was reduced to $2 \mathrm{~d}$ for subjects with ileostomies or ileorectal anastomosis because of reduced transit time (Hinton, Lennard-Jones \& Young, I969). After equilibration, faeces were collected for $3 \mathrm{~d}$. The faecal collection was weighed and homogenized (Laboratory Mixer Emulsifier; Silverson Machines Ltd, Chesham, Bucks.) with a known weight of distilled water.

\section{$N$ estimations}

The $\mathrm{N}$ content of paired, weighed portions of faecal homogenate was measured using a modified Kjeldahl digestion with a mercury catalyst (McKenzie \& Wallace, 1954). From this value, the daily faecal $\mathrm{N}$ excretion was calculated for each subject for the low- and high-protein diets.

Statistical analysis of the results was carried out using Student's $t$ test.

\section{RESULTS}

Increasing the amount of dietary protein, in all subjects, resulted in an increase in blood urea concentration (mean $\pm \mathrm{sE}$ ) from $3.63 \pm 0.31 \mathrm{rmol} / 1$ with the low-protein diet to $5.98 \pm 0.27 \mathrm{mmol} / 1$ with the high-protein diet. This increase was highly significant (paired $t$ test: $t 7 \cdot 925, P<0 \cdot 001$ ).

In control subjects neither faecal $N$ excretion $(g / d)$ nor faecal $N$ concentration ( $\mathrm{g} \mathrm{N} / \mathrm{kg}$ faeces) was increased significantly by increasing the amount of dietary protein (paired $t$ test: $t 2.489,0.1>P>0.05 ; t 0.906,0.5>P>0.4$ for low- and highprotein diets respectively (Table 1 )).

Conversely in subjects with nonfunctioning colons, increasing the dietary protein content resulted in a significant increase in both faecal $\mathrm{N}$ excretion $(\mathrm{g} / \mathrm{d})$ and faecal $\mathrm{N}$ concentration ( $\mathrm{g} \mathrm{N} / \mathrm{kg}$ faeces) (paired $t$ test: $t 3^{\cdot} \mathrm{I} 45, P<0.05 ; t 3^{\cdot 803}, P<0.02$ for low- and high-protein diets respectively (Table $\mathrm{I})$ ).

\section{DISCUSSION}

As this study was not carried out in the strictly controlled environment of a metabolic ward the highly significant increase in blood urea in all subjects on the highprotein diet was used as a simple indication that they had eaten the increased amount of protein served to them when they were given the high-protein diet (Addis, Barrett, Poo \& Yuen, 1947).

We have once again confirmed the reports of previous workers (Schamberg, Kolmer, Ringer \& Raiziss, I913; Reifenstein, Albright \& Wells, r945; Peters \& Van Slyke, 
Table I. Nitrogen content and weight of faeces from normal subjects and from subjects with an ileostomy or ileo-rectal anastomosis, given low- and high-protein diets providing 40 or $100 \mathrm{~g}$ protein/d

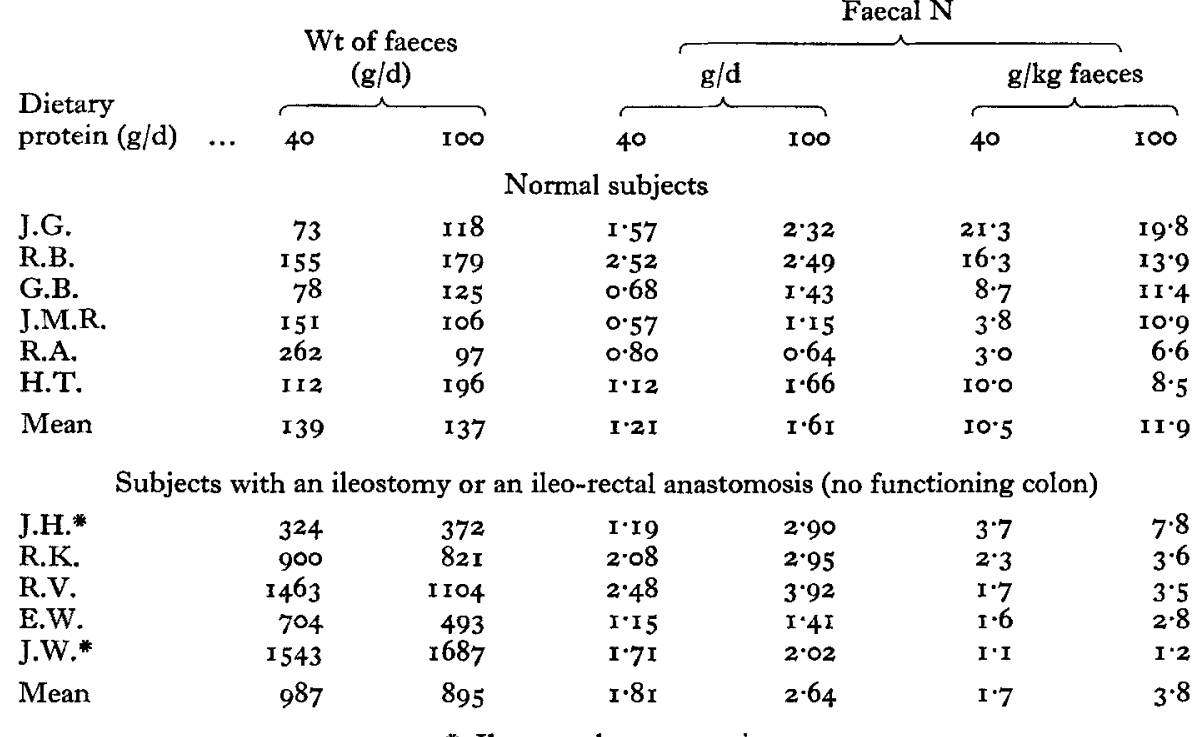

* Ileo-rectal anastomosis.

1946; McCance \& Widdowson, 1947) that the amount of faecal $\mathrm{N}$ is normally unaffected by variation in dietary protein content. Until now it has been assumed that the excretion of $\mathrm{N}$ from the small intestine into the colon would be similarly unaffected by variation in dietary protein content. This assumption results from the apparent efficiency of protein absorption by amino acid and peptide transport systems (Matthews, I97I) and also from the reports on protein absorption by Borgström, Dahlqvist, Lundh \& Sjövall (I957) and Nixon \& Mawer (1970). Using different methods these workers concluded that intestinal protein absorption was both rapid and efficient, being $80-90 \%$ complete in the first $1 \mathrm{~m}$ of the small intestine. Furthermore, Nixon \& Mawer (1970) suggested that beyond $\mathrm{r} .4 \mathrm{~m}$ most of the lumen amino acids would be endogenous in origin, a statement which is in agreement with the findings of Nasset (r964). These studies may be criticized because of the small protein loads used, and more recently, in studies using a simulated meal containing $5 \circ \mathrm{g}$ protein (equivalent to a standard meal), Adibi \& Mercer (1973) found significant quantities of dietary amino acids and peptides in the ileum. Also, they found no evidence of significant endogenous amino acid release after a protein-free meal.

In the present study we found a significant increase in ileal $\mathrm{N}$ output with increased dietary protein content in subjects without a functioning colon. Further we found that this increase takes place whether the ileal $\mathrm{N}$ output is expressed as an absolute amount or as a concentration ( $\mathrm{g} \mathrm{N} / \mathrm{kg}$ faeces) thus excluding the possibility that the increased N output resulted simply from increased faecal bulk (Mendel \& Fine, I9I2; Whitacre, Willard \& Blunt, 1929). In view of Adibi \& Mercer's (1973) finding that the ileum did 
not contain any significant quantities of endogenous amino acids, this increase in ileal effluent $\mathrm{N}$ must result from either increased unabsorbed dietary $\mathrm{N}$ or from the increased quantity of urea diffusing into the jejunum (Fordtran, Rector, Ewton, Soter \& Kinney, 1965; Sraer, Rambaud, Bernier \& Richet, 1971) as a result of the increase in blood urea concentration associated with increased dietary protein content. As we found that ileostomy urea concentration is approximately $70 \%$ of blood urea (J. A. Gibson, G. E. Sladen, N. Park \& A. M. Dawson, unpublished results) we can estimate the mean concentration of urea in the fluid delivered to the colon, for the two diets. From this and the mean daily ileostomy effluent volume of $960 \mathrm{ml} / \mathrm{d}$ we can calculate the amount of faecal $\mathrm{N}$ which resulted from urea diffusing into the bowel. On both diets this would only amount to $4 \%$ of the total $\mathrm{N}$. Thus the bulk of ileal effluent $\mathrm{N}$ results from dietary residue and not from endogenous urea.

In conclusion we suggest therefore that protein absorption by the small intestine is not $100 \%$ efficient and that an increase in dietary protein content results in a significant increase in $\mathrm{N}$ leaving the ileum. This $\mathrm{N}$ consists partly of unabsorbed dietary $\mathrm{N}$ and partly of cellular debris and intestinal secretions (Crane \& Neuberger, I960) but the increase is most likely to be of dietary origin unless some hitherto unknown mechanism enables dietary protein to stimulate endogenous $\mathrm{N}$ secretion. The difference between the amount of $\mathrm{N}$ in the faeces and that in the ileal effluent indicates that $\mathrm{N}$ is absorbed from the colon probably after bacterial metabolism (Donaldson, 1964; Evans, Aoyagi \& Summerskill, 1966; Vince, Dawson, Park \& O’Grady, 1973) as has been found in animals (Bayley, Cho \& Holmes, 1974).

These findings confirm the rationale of the current practice of controlling $\mathrm{NH}_{3}$ production in hepatic encephalopathy by dietary protein restriction.

The authors would like to thank Dr J. C. B. Fenton for his advice on faecal N estimation. This work was supported by the Research Board of St Bartholomew's Hospital, London.

\section{REFERENCES}

Addis, T., Barrett, E., Poo, L. J. \& Yuen, D. W. (1947). J. clin. Invest. 26, 869.

Adibi, S. A. \& Mercer, D. W. (1973). F. clin. Invest. 52, 1 586.

Bayley, H. S., Cho, C. Y. \& Holmes, J. H. G. (1974). Fedn Proc. Fedn Am. Socs exp. Biol. 33, 94.

Borgström, B., Dahlqvist, A., Lundh, G. \& Sjövall, J. (1957).F. clin. Invest. 36, 152I.

Crane, C. W. \& Neuberger, A. (1960). Br. med. F. ii, 888 .

Donaldson, R. M. Jr (1 964). New Engl. F. Med. 270, 938, 994, 1050.

Evans, W. B., Aoyagi, T. \& Summerskill, W. H. J. (I966). Gut 7,635.

Fordtran, J. S., Rector, F. C. Jr, Ewton, M. F., Soter, N. \& Kinney, J. (1965). F. clin. Invest. 44, 1935.

Hinton, J. M., Lennard-Jones, J. E. \& Young, A. C. (r969). Gut ro, 842.

McCance, R. A. \& Widdowson, E. M. (r947). F. Hyg., Camb. 45, 59.

McDermott, W. V., Adams, R. D. \& Riddell, A. G. (1954). Ann. Surg. 1oo, 539.

McKenzie, H. A. \& Wallace, H. S. (1954). Aust. F. Chem. 7, 55.

Martin, C. J. \& Robison, R. (1922). Biochem. F. 16, 407.

Matthews, D. M. (197I).F. clin. Path. 20, Suppl. 5, 29.

Mendel, L. B. \& Fine, M. S. (19r2). F. biol. Chem. rI, 5.

Nasset, E. S. (1964). Am. F. dig. Dis. 9, 175.

Nixon, S. E. \& Mawer, G. E. (1970). Br. F. Nutr. 24, 227.

Peters, J. P. \& Van Slyke, D. D. (1946). Quantitative Clinical Chemistry, and ed., vol. 1, p. 641. London:

Baillière, Tindall \& Cox.

Reifenstein, E. C. Jr, Albright, F. \& Wells, S. C. (I945). F. clin. Endocr. Metab. 5, 367. 
Vol. 35

Schamberg, J. F., Kolmer, J. A., Ringer, A. I. \& Raiziss, G. W. (1913). f. cutan. genito-urin. Dis. 31, 802.

Schenker, S., Breen, K. J. \& Hoyumpa, A. M. Jr (1974). Gastroenterology 66, 121.

Sherlock, S., Summerskill, W. H. J. \& Dawson, A. M. (1956). Lancet ii, 689.

Sherlock, S., Summerskill, W. H. J., White, L. P. \& Phear, E. A. (1954). Lancet ii, 453.

Sraer, J. D., Rambaud, J. C., Bernier, J. J. \& Richet, G. (I97r). Biologie Gastro-ent. 3, 2 I I.

Technicon Instruments Co. Ltd (1964). Technicon Publication no. UA4-or6oBoo. Chertsey, Surrey: Technicon Instruments Co. Ltd.

Vince, A., Dawson, A. M., Park, N. \& O'Grady, F. (1973). Gut 14, I71.

Whitacre, J., Willard, A. \& Blunt, K. (1929). F. Nutr. 2, 187. 